\title{
Preliminary Assessment of Chiropteran Fauna within Kayam Forest (Inocarpus fagifer) in Barangay Pagatpatan, Butuan City, Philippines
}

\author{
Glenn L. Betco ${ }^{*}$, Meljan T. Demetillo², Clyde Salanatin², Archie A. Along2, Alvin B. Goloran ${ }^{3}$ \\ ${ }^{1}$ City Environment and Natural Resources, City Government of Butuan, Butuan, Philippines \\ ${ }^{2}$ Department of Biology, College of Natural Sciences and Mathematics, Caraga State University, Ampayon, Butuan, Philippines \\ ${ }^{3}$ Pigdaulan National High School, Division of Butuan City, Department of Education, Butuan, Philippines \\ Email: *glennlbetco@gmail.com
}

How to cite this paper: Betco, G.L., Demetillo, M.T., Salanatin, C., Along, A.A. and Goloran, A.B. (2021) Preliminary Assessment of Chiropteran Fauna within Kayam Forest (Inucarpus fagifer) in Barangay Pagatpatan, Butuan City, Philippines. Open Access Library Journal, 8: e7251.

https://doi.org/10.4236/oalib.1107251

Received: February 17, 2021

Accepted: March 22, 2021

Published: March 25, 2021

Copyright $\odot 2021$ by author(s) and Open Access Library Inc.

This work is licensed under the Creative Commons Attribution International License (CC BY 4.0).

http://creativecommons.org/licenses/by/4.0/

\begin{abstract}
Bats conservation studies in Butuan City particularly within Kayam Forest are poorly studied and not even documented in the place. This study was purposely conducted to document and identify bats species in the unique forest. Diversity and assessment were conducted in different strategic locations along the portion of the lower Agusan River particularly in a well-known Kayam Forest (Inocarpus fagifer) in Butuan City, Philippines. The bats' assessment was made through the mist-netting captured-and-release method for species identification and composition. Morphometrics was used for the validity of species taxonomic identification up to the species level. A total of four (4) species of bats were identified within the Kayam forest comprising $15 \%$ of the total known Mindanao bats and 10\% of known Philippine bats, respectively. Among the identified bat species, Ptenochirus jagori was the most abundant species accounting for $57 \%$ of all total bats recorded followed by Macroglossus minimus and Cynopterus brachyotis with both obtained 19\%. The species Ptenochirus minor was the rare species observed. Of all species, two (2) Philippine endemic were recorded, and these are Ptenochirus minor and Macroglossus minimus. Both endemic species were encountered within the Kayam forest vegetation. Initial results revealed that the Kayam forest could provide a suitable environment for all identified species of bats. Considering the recorded endemic species, this study provides preliminary information to the local government for their proper implementation, conservation, and protection of this unique local vegetation.
\end{abstract}

\section{Subject Areas}

Environmental Sciences, Zoology 


\section{Keywords}

Preliminary Assessment, Philippine Bats, Kayam Forest

\section{Introduction}

The National Mapping and Resources Information Authority (NMRIA) recorded that Philippines has about 7641 islands containing major islands, the Luzon, Visayas, and Mindanao [1]. Philippines is regarded as mega biodiversity country due to its isolated island [2]. Among the animal group, mammalian fauna is the most striking species in the Philippines that includes bats or group chiroptera [3] and high endemic of fruit bats [4]. Philippine bats rely on most of the time in the primary forest [5]. Most bats hide mostly in caves and about 2000 caves have been documented in the Philippines [6] and play very important ecosystem functions [7] [8]. In the environment, fruit bats are interactors, pollinators, and seed dispersers in forest regeneration [3]. Conservation efforts for bats are usually roost [9] and less studied [6].

The Kayam forest (Inocarpus fagifer) is somehow unique primary forest in Butuan City and considered one of the city's eco-tourism sites. The City Environment and Natural Resources (City ENRO) recorded only bats as a whole and did not have data in its taxonomic identification and conservation or ecological status. Actual ocular inspection was conducted and turned out to be that the area was under threat due to human settlement, illegal logging and road widening development observed.

To address the issues on forest degradation and habitat loss within the unique Kayam Forest, this study purposely conducted to identify species composition and conservation status of group Chiropteran within the area and provide preliminary data to help local government units conserve its natural and unique potential eco-tourism sites within their vicinity and responsibility.

\section{Methodology}

\subsection{Site Description}

Kayam forest is only found within Butuan City particularly in Barangay Pagatpatan part of lower Agusan River Basin (ARB) with the following geographic locations: $8^{\circ} 98^{\prime} 784 \mathrm{~N} ; 125^{\circ} 52^{\prime} 686 \mathrm{E}$, elevation 72 meters above sea level. The area is dominated with Inocarpus fagifer species with some Arecaceae species such as Cocos nucifera and Nypa fruticans. Moreover Figure 1 shows the general map with sampling points. The actual field assessment recorded in the area had an average of humidity $69 \%$ and $31^{\circ} \mathrm{C}$ temperature, respectively.

\subsection{Sampling Procedure}

Since the study was just a preliminary assessment the sampling was conducted within the dry season months from December to May 2020 as a minimum re- 
quirement for rapid study [10] [11] [12]. Seven (7) mist nets were established perpendicular to the trail having at least 100 meter each segment and open for 6 hours as basic sampling unit [13]. The nets were checked for at least once per hour and open from sunset to sun dawn [14]. Figure 1 shows the location of each mist nets. Every captured bat was recorded, measured, identified and photograph. Red nail polish was used for marking the nails for every identified bat before releasing. No specimen or sample of bats collected.

\subsection{Bats Taxonomic Identification}

Bats were identified using the field guide to Bats of Philippine Island developed by Ingle and Heaney, 1992 [15]. Morphometrics was also recorded in every bat for finalization and confirmation of taxonomic identification up to species level.

\subsection{Conservation Status and Population Trends}

The conservation status and population trends for every bats were identified through the International Union for Conservation of Nature (IUCN) Red Lists and Department of Environment and Natural Resources (DENR) Order Number 09-2019 or list of threatened Philippine fauna and their categories. Population trends were recorded as decreasing or increasing.

\section{Results and Discussions}

A total of four (4) bats species were recorded belonging to family Pteropodidae order Chiroptera. The recorded Chiropteran species in Inocarpus fagifer forest or locally known as "Kayam Forest" are 10\% of Philippine known bats and 15\% in Mindanao, respectively. A total of 37 individuals of bats were recorded and all are considered fruit-bats. Among the individuals, Ptenochirus jagori (57\%) was the most abundant Chiropteran species followed by C. brachyotis (19\%) and $M$. minimus (19\%) (Table 1) (Figure 2).

The frequent presence of $P$. jagori in the forest could also provide information that the area is one of the best aerial routes and considered the best seed dispersal bats for I. fagifer trees. this species also known as natural and potential pollinators in the forest [16].

For conservation and ecological status of all identified bat species, two endemic bat species namely $P$. jagori and $P$. minor were noted. This means that the forest still holds these important species providing favorable habitat. All species are described as Least Concerned (LC) species by the International Union for Conservation of Nature (IUCN) red-list and not on the list of threatened plants under DENR Administrative Order 09-2019. Despite the commonality of all species, these groups of bats however is in population decreasing as noted by the IUCN Red List due to habitat loss and forest degradation [17]. Table 2 shows that overall information regarding the conservation status and population trends of all identified bat species. 

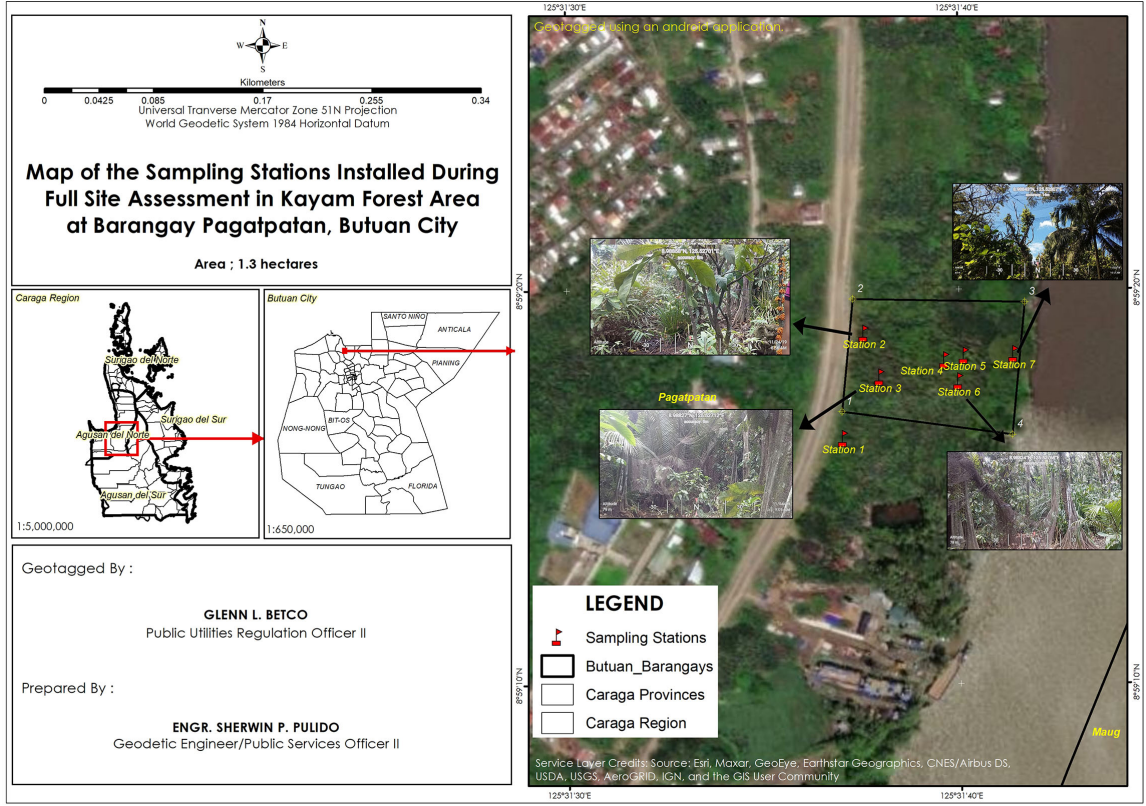

Figure 1. Study area shows the specific location of Inocarpus fagifer forest in Butuan City, Philippines.

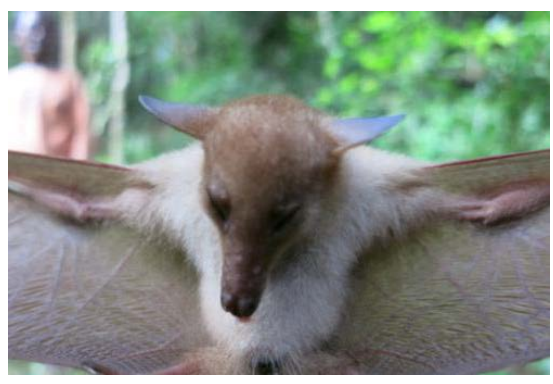

(a)

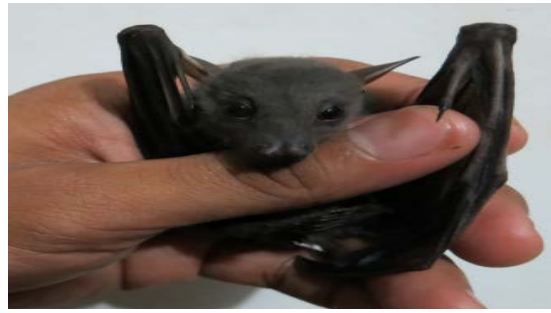

(c)

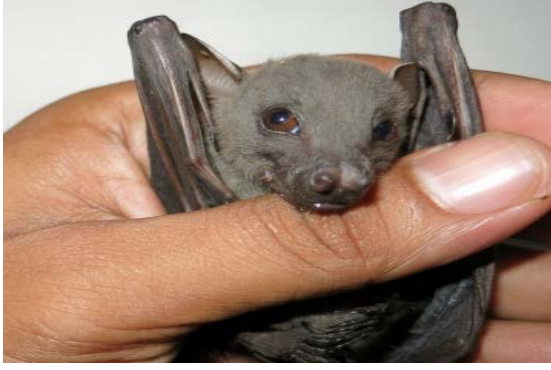

(b)

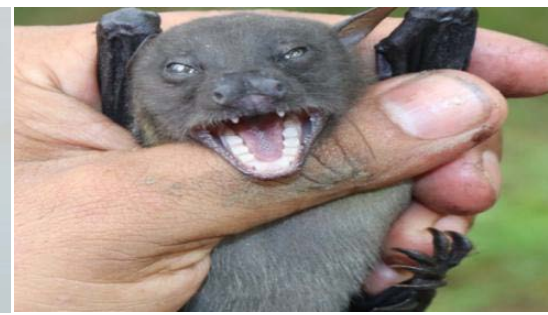

(d)

Figure 2. Species of Chiropteran found in I. fagifer forest (locally known as Kayam Forest). (a) C. brachyotis, (b)M. minimus, (c) P.jagori, (d) P. minor.

Table 1. Abundance of Bats species in I. fagifer forest.

\begin{tabular}{cc} 
Species & Abundance \\
\hline Cynopterus brachyotis & 7 \\
Macroglossus minimus & 7 \\
Ptenochirus jagori & 21 \\
Ptenochirus minor & 2 \\
Total & 37
\end{tabular}


Table 2. Conservation Status and Population Trends of all identified bat species.

\begin{tabular}{cccc}
\hline Species & Ecological Status & Conservation Status & Population Trends \\
\hline C. brachyotis & Widespread & Least Concerned & Decreasing \\
M. minimus & Widespread & Least Concerned & Decreasing \\
P. jagori & Endemic & Least Concerned & Decreasing \\
P. minor & Endemic & Least Concerned & Decreasing \\
\hline
\end{tabular}

\section{Conclusion}

The study provides initial information regarding the species composition and conservation status of Chiropteran bats in the I. fagifer forest (locally known as "Kayam Forest") of Butuan City, Philippines. Conservation plan by the local government unit must be continued considering that all species recorded were in population decreasing and two endemic species were recorded. This unique forest was dominated by $P$. jagori, a fruit bat species and could be one of the potential seed's pollinators of $I$. fagifer.

\section{Recommendations}

Protection and conservation in this remaining unique forest must be considered knowing that the forest is also a home for many bat species. Comprehensive assessment in wet and dry season for both flora and fauna must be considered in the future. The local government unit of Butuan City must craft protection plan for this kind of forest and must be included in the city's important plans such as forest land use plan (FLUP) and comprehensive land use plan in general (CLUP). Information and educational campaign must be considered to all people.

\section{Acknowledgements}

The researcher would like to extend and acknowledge the City Government of Butuan City through City Environment and Natural Resources \& City Tourism Office, the Barangay Pagatpatan and Officials, and the Department of Biology and Graduate Studies of Caraga State University, for the support of this study.

\section{Conflicts of Interest}

The authors declare no conflicts of interest regarding the publication of this paper.

\section{References}

[1] Goloran, A.B., Demetillo, M.T. and Betco, G.L. (2020) Mangroves Assessment and Diversity in Coastal Area of Barangay Cagdianao, Claver, Surigao Del Norte, Philippines. International Journal of Environmental Sciences \& Natural Resources, 26, 82-90. https://doi.org/10.19080/IJESNR.2020.26.556188

[2] Garcia, K., Gevana, D. and Malabrigo, P. (2013) Philippines' Mangrove Ecosystem: Status, Threats, and Conservation. In: Ibrahim, F.-H., Latiff, A., Hakeem, K.R. and 
Ozturk, M., Eds., Mangrove Ecosystems of Asia: Status, Challenges and Management Strategies, Mangrove Blue Carbon Project, Springer Science + Business Media, New York, 81-94. https://doi.org/10.1007/978-1-4614-8582-7 5

[3] Alcazar, S.M.T., Agbay, A.E., Lillo, E.P., Malaki, A.B., Alburo, H.M., Opiniano, R.P., Obiso, L.S., Hayohoy, G.B., Rica, R.L.V. and Manalastas, R.C. (2008) Fruit Bats Diversity in the Three Sites in Argao Watershed, Southern Cebu, Philippines. Tropical Technology Journal, 11, 1-8.

[4] Heaney, L.R. and Regalado, J.C. (1998) Vanishing Treasures of the Philippines Rainforest. The Field Museum, Chicago, 88 p.

[5] Heaney, L.R., Tabaranza Jr., B.R., Balete, D.S. and Rigertas, N. (2006) Synopsis and Biogeography 645 of the Mammals of Camiguin Island, Philippines. Fieldiana Zoology, 106, 28-48.

https://doi.org/10.3158/0015-0754(2006)106[28:SABOTM]2.0.CO;2

[6] Quibod, M.N.R.M., et al. (2019) Diversity and Threats to Cave-Dwelling Bats in a Small Island in the Southern Philippines. Journal of Asia-Pacific Biodiversity, 12, 481-487. https://doi.org/10.1016/j.japb.2019.06.001

[7] Kunz, T.H., de Torrez, E.B., Bauer, D. and Lobova, T. (2011) Ecosystem Services Provided by Bats. Annals of the New York Academy of Sciences, 1223, 1-38. https://doi.org/10.1111/j.1749-6632.2011.06004.x

[8] Medellin, R.A., Wiederholt, R. and Lopez-Hoffman, L. (2017) Conservation Relevance of Bat Caves for Biodiversity and Ecosystem Services. Biological Conservation, 211, 45-50. https://doi.org/10.1016/j.biocon.2017.01.012

[9] Martin, K.W., Puckette, W.L. and Hensley, S.L. (2000) Internal Cave Gating as a Means of Protecting Cave-Dwelling Bat Populations in Eastern Oklahoma. Proceedings of the Oklahoma Academy Science, 80, 133-137.

[10] Bodmer, R.E. (1990) Response of Ungulates to Seasonal Inundation in the Amazon Floodplain. Journal of Tropical Ecology, 6, 191-201.

https://doi.org/10.1017/S0266467400004314

[11] Peres, C.A. (1999) General Guidelines for Standardizing Line-Transect Surveys of Tropical Forest Primates. Neotropical Primates, 7, 11-16.

[12] Lehman, S.M. (2006) Effects of Transect Selection and Seasonally on Lemur Density Estimates in Southeastern Madagascar. International Journal of Primatology, 27, 1041-1057. https://doi.org/10.1007/s10764-006-9059-7

[13] Larsen, T.H. (2016) Core Standard Methods for Rapid Biological Field Assessment. Conservation International, Arlington, 61.

[14] Sikes, R.S. and Ganon, W.L. (2011) Guidelines of the American Society of Mammalogists for the Use of Wild Mammals Research. Journal of Mammalogy, 92, 235-253. https://doi.org/10.1644/10-MAMM-F-355.1

[15] Ingle, N.R. and Heaney, L.R. (1992) A Key to the Bats of the Philippine Islands. Fieldiana, Zoology, New Ser., No. 69, Publication (Field Museum of Natural History), 1440, Field Museum of Natural History, Chicago. https://doi.org/10.5962/bhl.title.3504

[16] Bacordo, C.D., Marfil, R.M. and Tabora, J.G. (2019) Fruit Bats as Natural Foragers and Potential Pollinators in Fruit Orchard: A Reproductive Phenological Study. Journal of Agricultural Research, Development, Extension and Technology, 25, 1-9.

[17] Laurindo, R.S., Novaes, R.L.M. and Vizentin-Bugoni, J. (2019) The Effects of Habitat Loss on Bat-Fruit Networks. Biodiversity and Conservation, 28, 589-601. https://doi.org/10.1007/s10531-018-1676-X 